\title{
Comparison of Territorial Spatial Planning System between China and Japan and Its Enlightenment
}

\author{
Xiaoping Zhou, Meng Zhao \\ School of Government, Beijing Normal University, Beijing, China \\ Email: zhaomengbnu@163.com
}

How to cite this paper: Zhou, X.P. and Zhao, M. (2017) Comparison of Territorial Spatial Planning System between China and Japan and Its Enlightenment. Journal of Service Science and Management, 10, 54-71. https://doi.org/10.4236/jssm.2017.101005

Received: January 14, 2017

Accepted: February 25, 2017

Published: February 28, 2017

Copyright $\odot 2017$ by authors and Scientific Research Publishing Inc. This work is licensed under the Creative Commons Attribution International License (CC BY 4.0).

http://creativecommons.org/licenses/by/4.0/ (c) (i) Open Access

\begin{abstract}
At present, China is carrying out "from the top to the bottom" governmentauthorized "Multi-planning United" reform pilot, exploring to establish "one city or county, one planning and one blue-print", improving the spatial planning system in the city and the county. The paper compares the spatial planning system between China and Japan in the planning compilation system, the management system and the legal system, and finds out that there are many types of plannings in China, each with different characteristics; the rights of the sector are separated and each planning system has their own rules; it's lacking in strategy and hard to implement; unified authority laws and regulations haven't been issued to secure the planning system. In terms of the results from "Multi-planning United" and the experience from Japan, the paper puts forward reconstructing spatial planning system, giving concrete suggestions on how to promote the planning system, the legal system, the coordinating management division and the unified information platform.
\end{abstract}

\section{Keywords}

China, Japan, Territorial Spatial Planning, Comparison, Multi-Planning United

\section{Introduction}

There are many types of spatial plannings in China, which are compiled, managed and implemented by the administrative departments of the government. Each planning system has their own rules and lacks correlations with the others. The overall objectives and the planning contents are contradictory, and the allocations of the space resources overlaps with each other. The lack of coordination 
or even conflicts among plannings weaken China urban space constraints, resulting in the frequently occurred phenomena that urbanization process squeezes agriculture and ecological space. The problem is basically the responsibility of the division-leading compilation and implementation of the planning which are too modularized. To deal with it, China urgently needs to reconstruct a scientific spatial planning system and changes the situation that many plannings exist under different leadership to achieve planning coherence and co-governance.

Spatial planning system refers to a system set up for coordinating different levels and types of spatial plannings and promoting a country's competence under the spatial goals like sustainable development when the industrialization and urbanization of a country has entered to a certain phase [1]. It consists of compilation system, management system, legal system and so on. Qualified planning system will streamline the regional planning management, improving the efficiency of the spatial resources utilization, achieving the coordinated development among population, resources and environment.

Since 1990s, there have been a lot of studies on the construction of the spatial planning system and the relations among different plannings in China, mainly referring to the management division, the coordinating mechanism, the key technologies and the applications of the results [2] [3] [4]. Some take a close look at the planning policies of the developed countries and its enlightenment [5] [6] [7] [8] [9]. But the studies on integrated spatial planning system are relatively less. Taking Japan for example, one of the significant features of Japan's territorial spatial planning system is that there are many types of horizontal planning levels and vertical planning levels, showing "multi-horizontal and multi-vertical" [10], which shares some similarities with China's existing "parallel cross" planning system. At the same time, tight constraints on space resources are also a common problem facing China and Japan in their sustainable economic and social development. However, Japan's planning system is more adaptable ${ }^{1}$. It can not only make timely adjustments in the content of spatial planning in accordance with the social environmental changes, but also keep consistence with compilation and coherent on operation, focusing on improving planning quality, strengthening the implementation of the planning, and promoting the efficiency of space resources utilization [11] [12] [13] [14] [15]. At present, the basic industrial spatial layout in Japan has been shaped, providing some experience in response to certain issues, including the unbalanced regional development, aging problem, and the relationship built between central and local government, etc. Therefore, it is necessary to deeply understand the overall design of Japan's territorial spatial planning system and compare the practice of China and Japan in planning, management and operation, laws and regulations, with a wish to reform and promote China's spatial planning system.

${ }^{1}$ From the focus on city establishment at the beginning, a complete system of the spatial planning in Japan has been accomplished for a shorter time compared with European countries, and it has been through five amendments since 1962. 


\section{Territorial Spatial Planning System in Japan}

Territorial spatial planning system in Japan is gradually established during the course of post-war economic construction. It features many types of horizontal planning and vertical planning levels and forms a network-based planning system with the economic plan.

\subsection{Compilation System of Territorial Spatial Planning in Japan}

Territorial spatial planning in Japan is divided into four categories: land formation planning, land use planning, land use basic planning and land use regulation (Figure 1). Japan attaches great importance to the compilation and coordination. The draft of the plan has been solicited the views of the whole society, and is asked for both straightening out the relations among various departments of land planning and economic planning and seeking the views of relevant departments of neighboring countries. The whole process may last up to 45 Months.

There are only two levels of land formation planning in Japan, which are national level and regional level. National land formation planning is basic principle, objective and national land policy developed by the state. The wide-area land formation planning is for two or more prefectures and districts designated by the government ordinance. The main contents are to formulate development policies, objectives, and territorial policies for the development of land in the area on the basis of national planning.

The main contents of land use planning include the basic conception of land use, the aim and the allocative direction of various types of land use, and the implementation measures. The compilation is highly targeted, and the subordinate planning needs to carry out under the guidance of the superior planning. This point shares great similarity with China's overall land use planning.

The land use basic planning is a grass-roots planning compiled by the government of each prefecture on the basis of public opinions. The planning is based on the land use planning of the whole country and each level of prefecture.

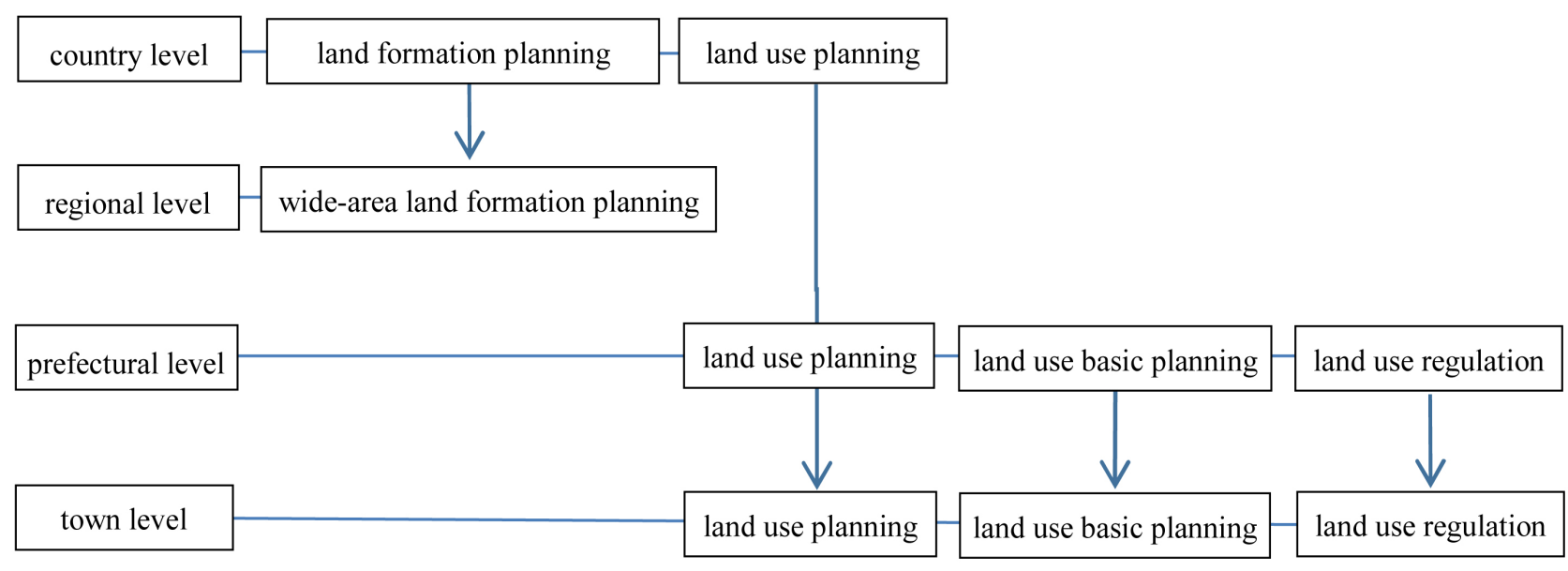

Figure 1. Territorial spatial planning in Japan. 
It mainly divides the land within the planning into several zones and manages them separately.

Land use regulation is a detailed land use planning in accordance with the regional specialized laws and regulations, which needs to be formulated on the basis of the basic land use planning, including urban planning, agricultural land revitalization planning and forest protection planning.

\subsection{Management System of Territorial Spatial Planning in Japan}

The management system of territorial spatial planning in Japan closely relies on its administrative system. At the central level, Ministry of Land, Infrastructure, Transport and Tourism is responsible for compiling and coordinating national land formation planning and land use planning at the national level. The National land formation planning is proposed by the Minister of Land, Infrastructure and Transport and Tourism, municipal government of the prefecture proposing a revisal advise with public participation in the evaluation. Once the compilation is set, the council will review the compilation and finally the cabinet will determine whether it is passed or not.

Wide-area land formation planning is compiled by the central government with multi-party participation including the participation of national and local government.

In the prefectural level, the land use planning shall be submitted to the Minister of the Cabinet, who shall consult with the Chief Executive of the relevant administrative agency and, at the same time, listen to the opinions of the Land Policy Review Committee and provide necessary advice to the prefectural government.

In the town-level, the work of territorial spatial planning administration is mainly carried out by the agriculture and forestry divisions of the industrial and construction departments, and the land use planning shall be reported to and reviewed by the governor of prefectures.

Planning agency at each level corresponds to different ranges of planning matters, which helps to build Japan's territorial spatial planning management system from top down.

\subsection{Legal System of Territorial Spatial Planning in Japan}

One of the distinct characteristics of territorial spatial planning in Japan is that the legislation is ahead of the planning. Through issuing laws of or related to the development of the land, Japan gradually has established a sound legal system of spatial planning. In these laws, "Land Formation Planning Act" and "Land Use Planning Act" are the major laws. "Agricultural Land Law" (1952), "Land Requisition Law" (1967), and "Agricultural Land Use Promotion Law" (1980) and so on are the supplementary.

In 2005, the new "Land Formation Planning Act" was issued to replace the "Comprehensive Land Development Law", making great changes in the concept and mode of land planning and the relationship between local and central gov- 
ernment with the focus on "new administrative subject". This law has also become the legal basis of the compilation of land formation planning.

\section{Current Status of the Extant Planing System in China}

The extant planning system in China is mainly composed of five parts, including plans for national economic and social development, main-functional zones, land-use, urban and rural development and environment protection. Based on departmental functions, a separate entity is formed among various types of plannings, each with different emphasis on the planning characteristics and division of labor arrangements.

\subsection{Compilation System of Spatial Planningin China}

Closely rely on the administrative level, China's planning compilation system has been divided into several levels from the top down, main plannings of which are forming a "parallel-cross" pattern. As shown in Figure 2.

As a comprehensive economic planning, the national economic and social development planning mainly is specified to the grand goals, main tasks and major initiatives of economic and social development, including overall planning, specialized planning and regional planning. The overall plans at all levels are the basis for the compilation of specialized and regional plans at the corresponding and subordinate levels, as well as the formulation of relevant policies and annual plans. The period for overall and regional planning in national and provincial levels is lasting about 5 years, while that for overall and specialized planning of the city/county level can be determined according to the actual needs. On the compilation scale, the overall and the specialized plannings will be extended to the township level, while regional planning is generally to the county level only. The main functional zone planning belongs to spatial comprehensive planning, which has been divided into national and provincial levels, emphasizing land space development pattern. As specialized planning for whole area space, the land-use planning is composed of the overall and the specialized plannings in land utilization, aiming mainly at strengthening the management of land resources. It has five levels, lasting for 15 years. The urban and rural planning belongs to comprehensive planning for local space, including urban system planning, urban planning, town planning, rural planning and village planning. And the urban planning and town planning have been subdivided into the overall planning and detailed planning. Generally, the planning period of overall plan for city and town is 20 years. Environmental protection planning is used to restrain exploitation, thus promoting sustainable development in environmental, economic and social aspects. It is usually placed as a specialized plan in the economic and social development planning sequence.

Centered on the general situation of national or regional development, various types of plannings formulate the overall ideas under the guidance of different departments, presenting a horizontal classification and vertical refinement of development goals and planning contents. 

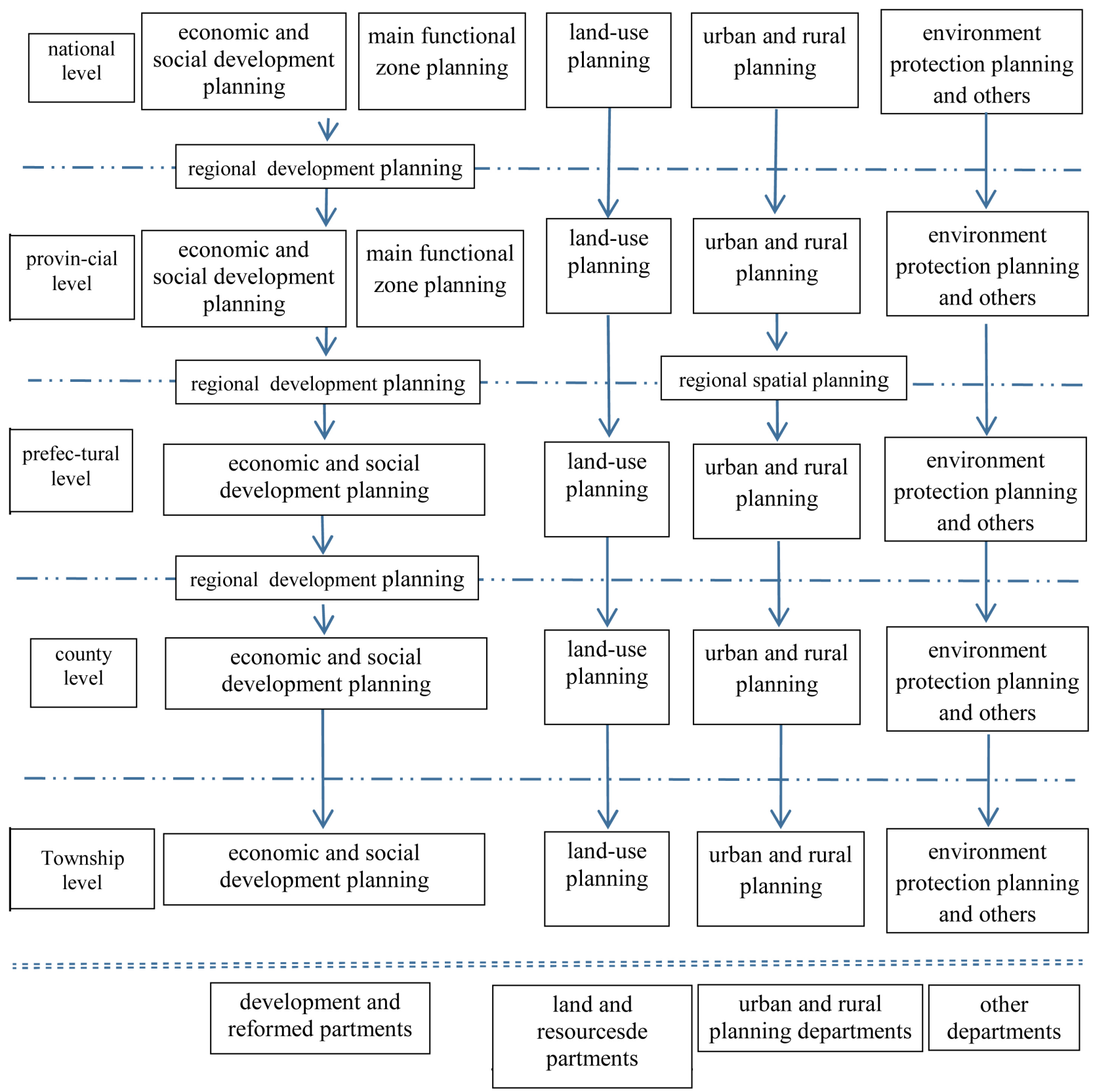

Figure 2. Current compilation system of spatial planningin China.

\subsection{Management System of Spatial Planningin China}

The overall planning for the national economic and social development at all levels shall be respectively formulated, undertaken, examined and approved at the same-level institutions, providing more guidance on implementation. Concretely, the formulation task shall be completed by the government, while the implementation task shall be undertaken by development and reform departments concerned, and the examination and approval work shall be in the charge of the people's congresses.

The main functional zone planning in national level shall be formulated by the leading group of compilation work in conjunction with the provincial govern- 
ment, specifically undertaken by the National Development and Reform Commission, and approved by the State Council for implementation. In provincial level, the planning shall be compiled by the city and town government under the organization of provincial government, and be specifically undertaken by development and reform departments at the corresponding level, and be approved by provincial government. The superior and local governments are responsible for its supervision. The planning emphasizes on guidance on implementation.

Land use planning shall be respectively compiled by the governments at all levels in accordance with economic development planning and superior land use planning, and shall be undertaken by departments of land and resources at the same level. This plan shall be examined for approval at different levels, among which the overall land-use planning in national, provincial and part of city levels shall be approved by the State Council, and the rest shall be approved by provincial government. The land use planning of the township shall be approved by the city government authorized by provincial government. And this plan is inclined to be implemented as a discipline.

The urban and rural planning, which is in the charge of the urban and rural planning departments, shall be formulated by the governments at all levels based on economic development planning and superior planning, and shall be specifically undertaken by the urban and rural planning departments in the corresponding level. This plan shall also be examined for approval at different levels. The "one proposal, two licenses" management system has been implemented in urban and county areas; the license for planned rural construction is issued in the planning area of town and village. And it is inclined to be implemented as a discipline.

With respect to environmental protection planning, both compilation and approval levels are relatively low. It shall be compiled by the environmental protection departments at all levels of government on the basis of economic development planning and the upper level planning, and shall be approved by government of the same level. The compilation should be linked up to other plannings, including mainfunctional planning, land-use planning and urban and rural planning, etc. As is shown in Table 1.

\subsection{Legal System of Spatial Planning in China}

The parallel characteristics of China's various plannings determine that the laws and regulations exist with mutual independence, and the laws are in the form of department laws. Currently there is no specific laws in economic and social development planning. "The Constitution of the People's Republic of China" stipulates that the State Council has the power to compile and implement national economic and social development planning, and authorizes the right of examination and approval to local people's congresses at or above the county level. In 2005, “The State Council's Opinions on Strengthening the Compilation of Na-

${ }^{2}$ Proposal for site-choosing, license for construction planning, license for project construction planning. 
Table 1. Current management system of spatial planningin China.

\begin{tabular}{|c|c|c|c|c|c|}
\hline planning & $\begin{array}{l}\text { economic and social } \\
\text { development } \\
\text { planning }\end{array}$ & $\begin{array}{l}\text { main functional } \\
\text { zone planning }\end{array}$ & land-use planning & $\begin{array}{l}\text { rural and urban } \\
\text { planning }\end{array}$ & $\begin{array}{l}\text { environment } \\
\text { planning }\end{array}$ \\
\hline department & $\begin{array}{l}\text { development and } \\
\text { reformed } \\
\text { partments }\end{array}$ & $\begin{array}{l}\text { development and } \\
\text { reformed } \\
\text { partments }\end{array}$ & $\begin{array}{l}\text { land and } \\
\text { resourcesde } \\
\text { partments }\end{array}$ & $\begin{array}{c}\text { urban and rural } \\
\text { planning departments }\end{array}$ & $\begin{array}{l}\text { environmental } \\
\text { protection } \\
\text { departments }\end{array}$ \\
\hline category & economic planning & spatialplanning & spatialplanning & spatialplanning & spatialplanning \\
\hline planning basis & $\begin{array}{c}\text { the upper level } \\
\text { planning }\end{array}$ & $\begin{array}{c}\text { the upper level } \\
\text { planning }\end{array}$ & $\begin{array}{l}\text { economic and } \\
\text { social development } \\
\text { planning and the } \\
\text { upper level planning }\end{array}$ & $\begin{array}{l}\text { economic and social } \\
\text { development } \\
\text { planning and the } \\
\text { upper level planning }\end{array}$ & $\begin{array}{l}\text { economic and social } \\
\text { development } \\
\text { planning and the } \\
\text { upper level planning }\end{array}$ \\
\hline $\begin{array}{l}\text { approving } \\
\text { authority }\end{array}$ & people's congresses & $\begin{array}{l}\text { the State Council or } \\
\text { provincial } \\
\text { government }\end{array}$ & $\begin{array}{l}\text { the State Council or } \\
\text { authorized } \\
\text { government }\end{array}$ & $\begin{array}{l}\text { the State Council or } \\
\text { superior government }\end{array}$ & $\begin{array}{l}\text { same-level } \\
\text { government }\end{array}$ \\
\hline implement-ation & guidance & guidance & discipline & discipline & discipline \\
\hline
\end{tabular}

tional Economic and Social Development Planning" further clarified the compilation and orientation of overall planning, specialized planning and regional planning in the economic and social development planning. At present, the "Development Planning Law" drafted by the National Development and Reform Commission is being prepared, with the purpose to incorporate the planning preparation into the legal framework, reducing arbitrariness.

"The Law of Land Administration of the People's Republic of China" is the main guarantee of the land-use planning. Besides, other ordinances and regulations are supplementary, including "Regulations on the Implementation of the Land Administration Law", "Regulations on the Protection of Basic Farmland", "Measures for the Making and Examination of Overall Land Use Plans" and so on.

The core law of urban and rural planning is "Urban and Rural Planning Law of the People's Republic of China", with many standard codes supported, such as "Measures for Formulating City Planning", "Measures for the Examination and Approval and the Formulation of the Provincial Urban System Planning", and "Measures for the Preparation, Examination and Approval of Detailed Control Plans on Cities and Towns".

In regard to environmental protection planning, the core law is the "Environmental Protection Law of the People's Republic of China", subordinating the single laws of "Water Pollution Prevention and Control Law of the People's Republic of China", "Atmospheric Pollution Prevention and Control Law of the People's Republic of China" and "the Law of the People's Republic of China on the Prevention and Control of Environment Pollution Caused by Solid Wastes", etc. There is also a range of environmental standards. But the technical norms

${ }^{3}$ Up to December 1, 2016, "Measures for the Examination and Approval and the Formulation of Overall Urban Planning (draft)" is under concertation; the future implementation of the approach will abolish the "Measures for Formulating City Planning". 
for the guidance of environmental protection planning have not been officially introduced so far.

The main functional zone planning is based on "Report to the Seventeenth National Congress of Communist Party of China"; "The Eleventh Five-Year Plan for National Economic and Social Development of the People's Republic of China" and "the State Council's Opinions on The Main Functional Zone Planning in China", which are operated mainly in administrative orders, yet having not risen to the national legal level. And it failed to cover all land space, and the technical norms are relatively weak.

\section{Problems of Existing Spatial Planning System in China}

The effective implementation of the Japanese national spatial planning, lies in its clear planning compilation system, the highly effective organization and management system and the well-established laws and regulations system. Compared with Japanese national spatial planning system, the planning system of China still has some deficiencies in such aspects as compilation, management, operation and law. The specific situation is as follows:

\subsection{Redundancy in Planning Types with Obvious Disparities of Elements on Compilation}

There are only four categories for Japan's national spatial planning compilation, with each level has no more than three types to facilitate the guidance of regional spatial development strategy. There are only two kinds of plannings in national level, that is land formation planning and land use planning. As both are compiled by Ministry of Land, Infrastructure, Transport and Tourism, it ensures the conformity of guiding ideology, planning elements, and planning objectives.

There are many classifications of China's planning without a recognized planning system. There are at least 83 kinds of authorized plannings in China [16], while much more uncountable types without legal basis are compiled by various departments in different regions; the departments and levels of planning are also in a great number. All of these result in the difference in the compilation specification and compilation target between superiors and subordinates.

As they belong to different departments, the planning elements differ in geographical information, primary data, land classification standard and valid term. For example, sections of the National Development and Reform Commission have their own geographic mapping system; departments of the Ministry of Land and Resources have remote sensing monitoring system; departments of the urban and rural planning also have its own system. On the access of primary data, land-use planning obtains it by remote sensing and field verification, and the data is completely closed; the urban and rural planning obtains the data by topographic map, cadastral map, remote sensing image and other methods in combination with field verification. In the classification criteria of different planning, their focus, land type and connotation is also inconsistent. For example, reservoir water surface belongs to non-construction land in the urban and 
rural planning, but it is included as construction land in the land-use planning. As for the compilation duration, the valid term of economic and social development plan is only 5 years, while land-use planning is 15 years and urban and rural planning is 20 years. Other plannings generally have their own planning duration.

\subsection{Great Separation of Departments with Self-Systems on Planning Management}

Japanese territorial spatial planning system has a unified coordination agency, under which the primary level departments are responsible for specific implementation. For example, reorganizing Ministry of Land, Infrastructure, Transport and Tourism and synchronizing the compilation of land formation planning and land use planning to ensure the consistency of planning ideas and value orientation.

In China, spatial planning system attaches great importance to the single category resources management, and pays less attention to the comprehensive management of multiple categories. The departments and approval levels of planning compilation are different. For example, economic and social development planning, land-use planning, urban planning and main functional zone planning are respectively compiled by each department under the organization of the government; the environmental protection planning is compiled by environmental protection department with relatively low status.

On the examination and approval, the people's congresses at the corresponding levels are responsible for the economic and social development plannings; the land-use plannings should be at least examined and approved by the city with districts; for the urban and rural planning, some county-level governments have approval rights. Even the examination and approval rights of some cities belong to the State Council or provincial government, the departments bearing the tasks are equal and independent on the ranks, which can deal with planning separately, such as compilation, implementation, evaluation and adjustment. Therefore, when plannings are working together on the same space, there will be inconsistent in management. In addition, the boundaries of planning management function is fuzzy, and lack of effective communication and coordination mechanism, these would make each department have to focus on their own planning, causing the rights of planning separated and isolated. Since each planning system has their own rules, the communication cost will increase in the long term, causing the deterioration of cooperation of different departments in the actual work.

\subsection{Lack of Strategies and Operabilities on Planning Operation}

The spatial planning in Japan has been relatively mature in the operation, with the upper-level planning focusing on strategic and policy and the lower-level focusing on operation. There is no complete affiliation between the spatial planning sequence, as all kinds of plans are parallel, and they are consistent in strat- 
egy and clear in assignments. For example, the land formation planning, land use planning and basic planning can achieve convergence in the concepts and guidelines. After the comprehensive land development planning changing into land formation planning, that is, four levels changing into two levels, the blue-print target was only emphasized by the high level, thus avoiding the contradiction among plannings of different levels, and becoming more conductive to the implementation of all types of plannings.

However, China's current planning system runs through the entire administrative levels (usually five levels), with the upper level planning lacking of strategy and policy and the lower level of planning simply imitating the superior planning, which resulted in weakness in operability and adaptability [17]. Diversification of planning types and departmentalization of compilation make each planning more focused in their own type while keeping dependence on each other, lacking overall planning and strategic co-ordination. This situation leads to the conflict of plannings in the spatial layout and function. Because the shortage in guidance of upper level spatial planning, there always appear different patterns. For example, land belongs to non-construction land in land-use planning, but it is used for construction in urban and rural planning.

Furthermore, in the vertical management mode of the block architecture in China, various operating units of lower level were caught in a "dilemma" between the local governments and superior departments. On the one hand, they should consider the development requirements of local governments; on the other hand, they need to combine the guidance requirements of department operation. This leads to the greater deviation of planning objectives and the resistance of implementation as things going on, and then the deformation of planning.

\subsection{Lack of Sound and Authoritative Laws and Regulations on Legislative Aspect}

Territorial spatial plannings of foreign countries have well-established unified authoritative laws as support. Japan has "Land Formation Planning Act" at the national level, formulating a unified policy of the formation of integrated land and determining the macro-strategy of land use. Meanwhile, there are various levels of basic laws and special regulations complement in each geographical area and special affairs. All of the planning formulation must be preceded by legislation.

On the contrary, China's current situation is that there co-exists a variety of plannings and departments have their own laws and regulations, some even don't have legal basis. Unified authority laws and regulations haven't been formed at the national level. The legal basis for planning is uneven, and most plannings were carried out under a power-based standard. In the higher economic and social development planning, in addition to the few provisions of the Constitution and the State [2005] No. 33 document, there exists almost no other legal and regulatory basis, the normalization and legislation process are lagging 
behind. However, other laws have stipulated that the compilation of each department planning must be based on the economic and social development planning. Due to the lack of authority of legal provisions, there is a relatively large elasticity in the planning implementation. Although the law stipulates that urban and rural planning should be integrated with the land use planning, and regional planning needs to take full account of the overall land use planning, urban and rural planning and other requirements, the reality of the implementation is full of "obfuscation". Mutual convergence becomes mutual game. Landuse planning in lagging areas is more inclined to give place to urban and rural planning to expand the scope of the city.

\section{Suggestions of Reform in China's Spatial Planning System}

From the above comparison, we can see that separation of departments' power and conflicts of interest are main factors that hamper the effectiveness of China's spatial planning. In terms of the results from "Multi-planning United" pilot practice, it's necessary to reinforce the design of top-level system and propel "Multi-planning United" with prudence. In 2005, the CPC Central Committee and the State Council issued "Overall Plan for the Reform of Eco-civilization System", and proposed to formulate spatial planning system at national level, provincial level and city-county level. The city-county means prefecture-level city, while "Multi-planning United" pilot indicates that the effect of prefecture-level city is limited between provincial level and county level.

Therefore, we suggest that national vertical spatial planning system extends to county level and formulates spatial planning system at national level, provincial level and county level. We also suggest the government to set up an independent institution to break down the interest fence among departments and to reconstructspatial planning system so as to achieve coherence and coordination of "Multiple-plan", and solve the contradictions and conflicts between each planning by planning compilation, laws and regulations, regulatory agency and information platform.

\subsection{Improve the Spatial Planning System and Enhance the Adaptability of Planning}

The establishment of spatial planning compilation system is the key factor for effective operation of the planning. At first, we need to make clear the positioning of planning and construct a three-level planning compilation system (Figure 3) led by national integrated planning and supported by specialized and detailed planning based on the evaluation of resources and environmental carrying capacity [18], to achieve "Multiple-plan" collaborated by "blue-print". From central government to county-level government, from the top to the bottom, we need to recognize clearly the primary and secondary relation of integrated planning and other plannings: integrated planning is the top-level guide planning focusing on strategy and policy and is in charge of overall plan and coordination in the region; department plannings are specialized plannings and detailed plannings 


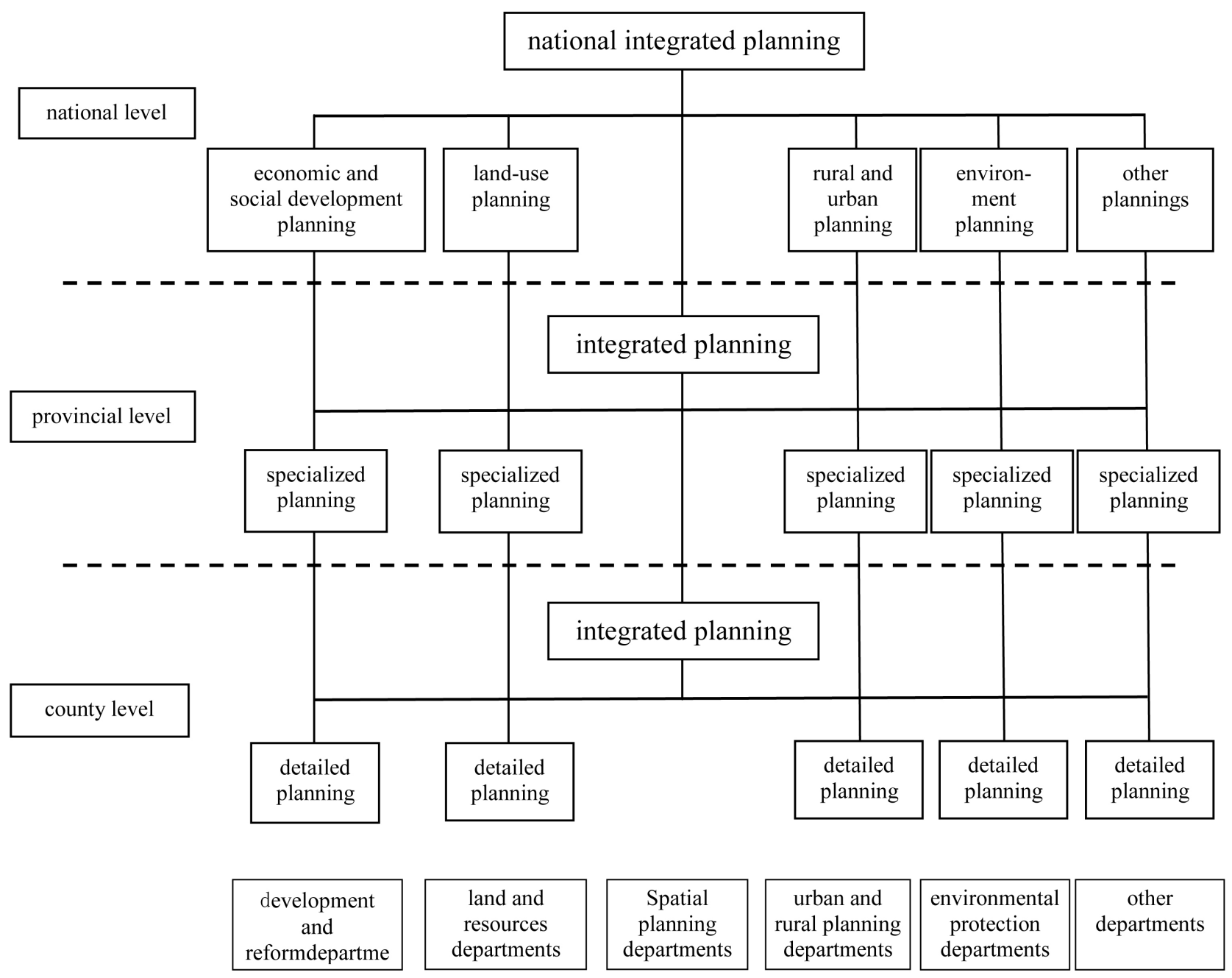

Figure 3. Compilation system of spatial planning in China.

focusing on operation and adaptation and are responsible for implementation.

Compilation of integrated planning needs each department to give full play to their superiority, integrate core objectives of department plannings, build consensus and form a common action guidelines. The content includes development strategy, planning objective, spatial pattern and so on. In respect of planning control, we need to determine spatial integrated planning's control line according to core indexes of each planning. According to targeted index determined by integrated planning, specialized planning of each department plays its professional role combining its own function. Each specialized planning obeys integrated planning and guides detailed planning to implement what the objective requires.

Compilation, approval and amendments of various kinds of plannings must be proceeded under "blue-print" of integrated planning. Exploitation, utilization and protection of territory must be carried out under relevant management and demands of planning control line. While formulating planning, the government should publish the planning draft and take in ideas and suggestions from planning unit, builders, the administration and the public to enhance the scientific 
nature and rationality of planning. In the meantime, establish the system evaluated and adjusted every five years, and synchronize and unite the formulation of integrated planning, specialized planning and detailed planning. Simplify planning levels, cancel the setting of prefecture-level city's plannings, make sure that provincial level planning connects to county level planning directly and reduce internal consumption caused by poor communication and approval redundancy.

\subsection{Improve Spatial Planning Laws and Regulations System and Standardize Planning Operation}

Perfect laws and regulations ensure the formulation, operation and management of spatial planning system. In Japan, the effective implementation of territorial spatial planning has benefited greatly from its relatively integrated systems and platforms for laws and regulations. However, the major form of spatial planning laws in China now is department regulation, short of trunk laws in whole. We suggest that, combining national spatial development strategies in the future on the basis of the current laws, the "Law of National Spatial Planning" should be put forward as authorities in this area. Through a clear explanation of the spatial planning system, and the basic contents of various plannings, including the properties, positioning, details, the main bodies and procedures of compilation, the budget and implementation, and so on, the law is supposed to streamline the legal relations, providing guidance for the coordination and integration of spatial planning. Simultaneously, revise and improve other relevant laws, formulating relevant administrative regulations in coordination with the "Law of National Spatial Planning" to ensure the effective convergence in the legal level.

At the same time, the laws and regulations system should be formulated with correspondence to the spatial planning system, covering the contents of planning formulation, planning execution, planning conflict coordination, planning supervision and so on. Establish legalized planning coordination model, and standardize the process of application, acceptance, trial and judgment when disagreements arise. With the improvement of planning laws and regulations system, power's intervention on plannings shall be restrained, thus assuring the orderly space exploitation under constrains of the law.

\subsection{Set up Coordinated Management Agencies and Standardize Authorities of Approval and Supervision}

Management agency is a carrier to guarantee the effective implementation of spatial planning system. Therefore, the conflicts of interest among departments should be resolved, which to break down the barriers of administrative boundaries and departmental separations. In respect of organization structure, spatial planning should adhere to the work pattern with the Party committee in the lead, the government being responsible for organization and all departments providing collaboration. It can be taken into consideration that setting up a committee for spatial overall planning at each level, with the main administra- 
tive leaders in charge, so as to provide a platform for normalized communication of planning among departments. A standing office shall be established there for daily organization and coordination of planning. The planning committee will centralize the compilation authorities dispersed in each department, and take charge of the overall planning formulation and coordination of each specialized planning. But the specialized and detailed plannings shall be formulated still by various departments, and they should be submitted to the overall planning committee for the record.

On the approval and supervision, there are three pieces of advice, first of which is to strengthen the administrative system on the usages of national space, and the second one is to establish the principle of "whoever approves is responsible for its supervision". The third one is to retain the approval authority only in the People's Congress of three levels, including national, provincial and countylevels. In detail, the integrated planning in national level shall be approved by national people's congress, with the submission to the State Council for the record. In provincial level, the planning shall be approved by the provincial people's congress, with the submission to national spatial overall planning committee for the record. In countylevel, the planning shall be approved by the countylevel people's congress, with the submission to provincial spatial overall planning committee for the record. In this way, the coordination among overall plannings, specialized plannings, detailed plannings and relevant policies shall be strengthened, making sure of the unity and enforcement of the plannings.

\subsection{Unify the Spatial Planning Elements and Set up a Planning Information Platform}

The unified planning elements and information platforms are the foundation of spatial planning implementation. We suggest that, in the leadership of "Multi-planning United" group, employ legal and technical methods to realize the unification of planning contents and purposes. Specifically, first is to analyze the coordination of "multi-planning" space, refining the land-use classification in accordance with land-use planning and urban and rural planning on the basis of the status, so as to achieve a consistence among land-use standards. Second, based on the second national land investigation data and the latest data in continuous change, combining many research results from the special investigation of natural resources, the general survey of geography, and the geological environment investigation, conduct a united coordinate of muti-planning space data to form a set of shared basic data system, highlighting the supporting role of the "basic data and map". The standard geographic information system shall be applied for comparison, in order to eliminate all kinds of planning differences. Set the year of 2020 as the recent transition period, and the planning period is standardized to 15 years, with the final goal to realize the normalization of planning elements.

On the basis of unified planning elements, build a nationwide spatial database featured in vertically sharing online, horizontally interconnecting with each 
other, and crossly big data fusing. In coordination with the business subsystems in development and reform department, land and resources bureau, construction and planning department and environmental protection bureau, construct a public information platform facilitated for unified management, update and maintenance of the overall planning results and data, therefore to realize the seamless convergence and dynamic feedback of the basic geographic information, the planning space management information and the approval data of construction project.

\section{Conclusions}

Territorial spatial planning has great influence on the development direction of a region, or even a country. It is a measure for the government to manage the society and also a way to achieve development of society. In China, there are many types of plannings, each with different characteristics; the rights of the sector are separated and each planning system has their own rules; it's lacking in strategy and hard to implement; unified authority laws and regulations haven't been issued to secure the planning system. The reason why the system has so many flaws is that the division-leading compilation, management and implementation are too modularized, with planning elements, objectives and interests contradictory with each other, making it hard to form a united and complete spatial planning system. In comparison, Japan's experience of compilation, management and implementation is very enlightening. Therefore, breaking the barriers among the departments as well as the power monopoly and information bulwark consequently, optimizing and improving the compilation and operation, the management division, and laws and regulations on planning shall be given the priority when practicing "Multi-planning United" in the future.

The ultimate result of "Multi-planning United" should be the "integration" of plannings instead of the "mixture" of each planning. It is necessary to construct a rational and orderly integrated spatial planning system. forming a three-tier planning system led by spatial integrated planning, supported by specialized plannings and detailed plannings. Through sound laws and regulations, the position of spatial comprehensive planning shall be made clear, with the function and the possibility of practice of the planning being enhanced. Through the "multi-planning" coordinating management agencies, the compilation will be consistently operated. Through the united planning contents and information platform, overall planning is able to achieve effective integration. First of all, pay attention to the level and type settings in vertical planning system. There shall be a top-down formation of national, provincial and county levels, respectively corresponding to three types of integrated spatial planning, specialized planning and detailed planning, so as to form a complete and orderly planning system and enhance planning adaptability. Second, perfect the law and regulation system of spatial plannings and definite the position of integrated spatial planning, thus to normalize the planning operation and promote its authority and operability. Third, break the interest barriers among departments through independent 
agencies, thus to regulate the power of compilation, approval and supervision, and coordinate the compilation and coherent implementation of integrated planning. At last, unite the spatial planning components and set up an information platform, realizing the identification among components and the seamless convergence and dynamic feedback of data information. All of these can promote the structure of industry, life and ecological space and improve the harmonious and sustainable development of population, resources and environment.

\section{Funded Project}

The integrated national "Multi-planning United" pilot projects: Compilation of Yulin Spatial Planning (2015-2030).

\section{References}

[1] Zhou, J.M. and Luo, X. (1998) An Assessment of Actual Effects and Study of the Development Counter-Measures of China's Spatial Planning System. Planners, 4, 109-112.

[2] Zhu, C.B. (1999) The Coordinate Mechanism of General Urban Planning and Land Use Planning. Urban Planning Forum, 4, 10-13.

[3] Wang, G.E., Tang, Y., Wei, Z.C. and Jing, W.L. (2009) A Study on the Coordination of Urban Master Planning and General Land Use Planning-A Case Study of Guangzhou. Journal of Urban Planning, 5, 20-27.

[4] Lai, S.H., Huang, H.M., Chen, J.P. and Chen, X.M. (2013) From Technical Innovation to Institutional Innovation: "Three-Plan-Coordination" Practices in Heyuan, Yunfu and Guangzhou. Journal of Urban Planning, 5, 63-68.

[5] Cai, Y.M., Deng, H.D. and Tan, Q.Y. (2005) Germany Territorial Planning: Sound Mechanism, Integrity System, Perfect Legal Mechanism. Land and Resources, 1, 4447.

[6] Lv, X.H. (2014) The Significance of the New Spatial Planning System for Rural Development in the UK. Urban Planning International, 4, 77-83.

[7] Healey, P. (1992) Planning through Debate: The Communicative Turnin Planning Theory. Town Planning Review, 63, 143-162. https://doi.org/10.3828/tpr.63.2.422x602303814821

[8] Neuman, M. (1998) Does Planning Need the Plan? Journal of the American Planning Association, 64, 208-220. https://doi.org/10.1080/01944369808975976

[9] Thompson, R. (2000) Re-Defining Planning: The Roles of Theory and Practice. Planning Theory \& Practice, 1, 126-133. https://doi.org/10.1080/14649350050135248

[10] Cai, Y.M., Wang, G.L, Lu, Y., Han, Z.L. and Li, J.Y. (2014) Inspirations That We Gained from the Mode of International Space Planning System. Natural Resource Economics of China, 6, 67-72.

[11] Zhou, S.Y., Zhang, G.Y. and Xu, X.L. (2000) The Materialization of Japanese Fifth Country Land Plan in the Regional Land Plans. Geographical Research, 4, 400-406.

[12] Pan, W.C. (2003) The Territory Planning of South Korea and Japan. China Geology and Mining Economics, 8, 15-18.

[13] Jiang, Y. (2010) The Latest Territory of Japan-The Formation. Land and Resources Information, 3, 14-19.

[14] Zhai, G.F. (2009) Evolution and Implication of Japanese Spatial Planning. Urban 
Planning International, 4, 85-90.

[15] Lu, X.H. (2011) Japan's Comprehensive National Development Plan Reform. Urban Studies, 5, 34-37.

[16] Cai, Y.N. (2009) The Thinking and Exploration of Four Major Urban Planning and Coordination in the New Period. Planners, 1, 22-25.

[17] Wang, X.D. and Liu, W.D. (2012) Spatial Planning System in China: Status, Problems and Reconstruction. Economic Geography, 5, 7-15.

[18] Sun, X.M. (2015) Research on Low-Carbon Transformation in Resources-Based Cities. Economic Science Press, Beijing.

Submit or recommend next manuscript to SCIRP and we will provide best service for you:

Accepting pre-submission inquiries through Email, Facebook, LinkedIn, Twitter, etc. A wide selection of journals (inclusive of 9 subjects, more than 200 journals)

Providing 24-hour high-quality service

User-friendly online submission system

Fair and swift peer-review system

Efficient typesetting and proofreading procedure

Display of the result of downloads and visits, as well as the number of cited articles Maximum dissemination of your research work

Submit your manuscript at: http://papersubmission.scirp.org/

Or contact jssm@scirp.org 